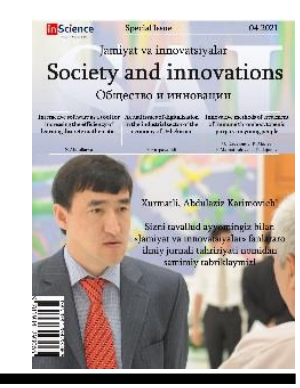

\title{
Linguo psychological features of units of personality in English and Uzbek languages
}

\section{Zebo MENGINIYOZOVA ${ }^{1}$}

National University of Uzbekistan

\begin{tabular}{l} 
ARTICLE INFO \\
\hline Article history: \\
Received March 2021 \\
Received in revised form \\
20 March 2021 \\
Accepted 15 April 2021 \\
Available online \\
20 May 2021
\end{tabular}

\section{Keywords:}

phraseological units, linguaculturalogy, equivalent, culture of speech, transformation, component.

\section{ABSTRACT}

The point of the show article is to appear a few issues of interpretation phraseological units from English into Uzbek dialect in see of them linguacultural highlights. The dialect culture of the individual is shaped at interaction of wonders "culture of dialect" and "culture of speech". In its premise the information of standards of composed and verbal discourse, semantic and expressive openings of framework, think about excellent craftsmanship, publicisticand a few other writings lays.

2181-1415/C) 2021 in Science LLC.

This is an open access article under the Attribution 4.0 International (CC BY 4.0) license (https://creativecommons.org/licenses/by/4.0/deed.ru)

\section{Ingliz va o'zbek tillaridagi shaxsiyat birliklarining lingvopsixologik xususiyatlari}

Kalit so'zlar:

frazeologik birliklar, lingvakulturologiya, ekvivalent, nutq madaniyati, o'zgarish, tarkibiy qism.

\section{ANNATATSIYA}

Ko'rgazma maqolasining mazmuni shundaki, frazeologik birliklarni ingliz tilidan o'zbek lahjasiga talqin qilishning bir nechta masalalari, ularni lingvakultural xususiyatlarini ko'rib chiqishdir. Shaxsning dialect madaniyati "dialect madaniyati" va "nutq madaniyati" mo'jizalarining o'zaro ta'sirida shakllanadi. O'zining asosida kompozitsiya va og'zaki nutq standartlari, ramkaning mazmunli va ifodali ochilishi, mukammal mahorat, publitsistik va boshqa bir qator yozuvlar haqida ma'lumot beradi.

\footnotetext{
${ }^{1}$ Lecturer, National University of Uzbekistan. Tashkent, Uzbekistan.
} 


\section{Лингвопсихологические особенности единиц личности английского и узбекского языков}

\author{
Ключевые слова: \\ фразеологические \\ единицы, \\ лингвокультурология, \\ эквивалент, \\ культура речи, \\ трансформация, \\ компонент.
}

\begin{abstract}
АННОТАЦИЯ
Смысл представленной статьи состоит в том, чтобы осветить несколько вопросов интерпретации фразеологизмов английского языка на узбекский диалект с точки зрения лингвокультурологических особенностей. Диалектная культура личности формируется при взаимодействии чудес «культуры диалекта» и «культуры речи». В его основе лежит информация о стандартах сочиненного и вербального дискурса, семантических и выразительных открытиях рамок, размышления о превосходном мастерстве, публицистике и некоторых других произведениях.
\end{abstract}

We live in a period of globalization, so the significance of information of outside dialects is expanding each day. As a result, investigate on the issues of communication between societies and people groups is getting to be increasingly seriously. In this way, dialect being a critical implies of concentrating data around the world, at the same time acts as the foremost critical sign of a specific individuals. It is in dialect that the mindset of the individuals, their brain research, traditions and mores are most clearly expressed. It may be implying of making national writing, the most store of data almost specific individuals [1].

The national attitude is showed within the reflection of the idiosyncrasies of life, traditions, history and culture, basically phraseological units. One of the highlights of sayings is to deliver individuals an appraisal of the objective wonders of reality, thereby expressing the worldview. Within the phraseological units is communicated the unconventional attitude, a way of judgement, the include sees; they show the life and life, soul and mood, conduct and traditions, convictions and superstitions.

Phonetic and social examination of phraseological units is connected outside variables: the history of the nation, its culture, daily life, etc. the Think about of phraseological units within the linguistic and social viewpoint makes a difference to clarify, and in a few cases to set up extra semantic shades with national and social semantics.

Phraseological units, sayings and truisms respond to all marvels of reality, reflect the life and worldview of the individuals in all its differing qualities, they pass on each day, social, philosophical, devout, ethical, moral and tasteful sees of the individuals. And with this assignment adage adapt exceptionally effectively. Their subject matter is boundless. $s$ genuinely boundless. They cover completely all perspectives of human life, the foremost different connections between distinctive marvels of reality [2].

Within the idiomatics of the language, that's, within the layer that's, by definition, broadly particular, the framework of values, open profound quality, state of mind to the world, to individuals, to other people groups is shown. Phraseological units most clearly outline the way of life, geological area, history, and conventions of a specific community Joined together by a single culture. 
In traditionally oriented linguistics, such problems and tasks are constantly being posed and formed that can no longer be solved by means and methods that are ingrained in science, but require the use of syncretic logical-linguistic, psycholinguistic, and sociolinguistic methods for studying the linguistics of a text. In our opinion, linguoculturology as a special area of analysis is brought to life by such a statement of the question [3].

Problems of translating phraseological units from English into Uzbek, taking into account their linguistic and cultural characteristics, is considered to be one of the most difficult types of translation transformations. The object of translation is not a language system as an abstraction, but a specific speech work in another language (the original text), on the basis of which another speech work in another language (the translation text) is created. The purpose of the translation is to acquaint the reader (or listener) who does not know the original language as closely as possible with this text (or the content of oral speech). To translate means to express correctly and fully by means of one language what has already been expressed by means of another language. Achieving translation equivalence (translation adequacy), despite the differences in the formal and semantic systems of the two languages, requires the translator to first of all be able to make numerous and high-quality interlanguage transformations - so-called translation transformations-so that the translation text conveys all the information contained in the source text as fully as possible, while strictly observing the norms of the translating language[4].

A.V. Konin gives the following definition of phraseological units: "a Phraseological unit is a stable combination of words with a completely or partially reinterpreted meaning" (Koonin,1996: 5).

V.N. Komissarov tells about three correspondence types with figurative phraseological units of the originals. (Kobiakova, 2017: 4)

1. Phraseological equivalents. In this case, a similar idiom that corresponds to all the parameters of the original idiomatic expression is meant. However, there are two factors to be considered: phraseological equivalents are relatively few and when the same idiom is borrowed by two languages, its meaning may be changed in one of them, and these idioms may be "false friends of the translator" - similar in form but different in content" (Komissarov, 2004: 172).

2. Phraseological analogies. This is an idiom with the same figurative meaning as the original, although based on a different form. Here the author also notes some limitations. Firstly, it is necessary to ascertain that emotional and stylistic meanings of the idiom are kept. Secondly, this method of translation is not suitable when the idiom that is to be translated has an explicit pronounced national character (Komissarov, 2004: 174).

3. The calque of the foreign language figurative unit. The author believes that the calque allows keeping the original imagery and makes it possible to overcome the difficulties that arise when the image in original is made to create an extended metaphor (Komissarov,2004: 174).

It is usually accepted to indicate the equivalent of a phraseological unit to a word. However, the theory of complete equivalence is becoming obsolete. This does not mean that phraseological units and words have nothing in common, which is considered by the theory of correlation of certain types of phraseological units and words, which, however, 
is based on slightly different principles. The most characteristic for phraseological turns of stable combinations of words are in principle equal in meaning to a single word, differing from it, as a rule, by a certain expressive and stylistic coloring [5].

The classification of phraseological units also contains the necessary theoretical knowledge for the translator, with which we can identify the phraseological units in the text, then analyze it and, based on the analysis, give the most accurate translation in this context. The most legitimate approach is to consider phraseological units in three aspects: semantic, structural-grammatical, and component. Taking into account the marked levels, the following types are distinguished:

1) phraseological equivalents (full and partial) - phraseological units with identical semantics, structural and grammatical organization and with identical component composition;

as brave as a lion - sherday qo'rqmas;

as hard as iron - temirday baquvvat;

high blood - qoni qaynoq;

have a heart - yuragi bor (mehrli)

milk cow - sog'in sigir.

2) phraseological analogs (full and partial) - phraseological units that express the same or similar meaning, but are characterized by a complete difference in the approximate similarity of the internal form;

blood from/out of a stone - tosh bag'ir.

as honest as a man as ever broke bread - qo'y og'zidanc ho'p olmagan.

talk turkey - ochiqdan - ochiq gapiradigan

take off one's coat - asl yuzini ochib tashlamoq.

3) non-equivalent phraseological units - phraseological units that do not have correspondences in the phraseological system of another language.

to be in somebody's corner - ichimdagini top.

to hit the roof-tutgan joyidan uzadi.

In conclusion, the task of the translator is to understand the meaning of the source text and express the same meaning (more precisely, the system of values) by means of a different language. In this case, an interlanguage transformation occurs, i.e., the replacement of one sign system with another, which leads to inevitable semantic losses. The translator must keep them to a minimum, i.e. ensure a greater degree of equivalence between the source text and the translation text, which is impossible without performing various translation transformations.

\section{REFERENCES:}

1. Gak V.G., Lvin Yu. I. translation Course: French. Moscow, 1970. - P. 59.

2. Koonin A.V. phraseology Course of the modern English language. - Moscow: Higher school, 1996. - P. 5.

3. Komissarov V.N. Modern translation. - M.: ETC, 2004. - P. 424.

4. Kobiakova I.K. Translation aspects of quantitative phraseological units. Research gate. 2017. - P. 4.

5. Arsentyeva Y.F. Comparative analysis of phraseological units - Kazan, 1989. - P. 126. 